\title{
INTRODUCTION \\ On pandemics: the impact of COVID-19 on the practice of neurosurgery
}

\author{
Doug Kondziolka, MD, FRCSC, ${ }^{1}$ William T. Couldwell, MD, PhD, ${ }^{2}$ and James T. Rutka, MD, $\mathrm{PhD}^{3}$

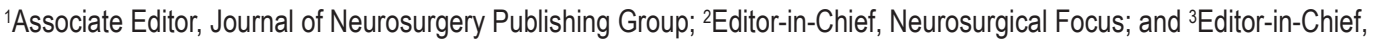 \\ Journal of Neurosurgery Publishing Group, Charlottesville, Virginia
}

$\mathrm{O}$ $\mathrm{N}$ January 8, 2020, a prescient scientific article was submitted for publication to the Journal of Travel Medicine on a pneumonia of unknown etiology that was identified in patients in Wuhan, China, and the potential for its international spread through commercial air travel. ${ }^{1}$ This article was in direct response to a communication from the World Health Organization, which reported on 44 patients with pneumonia from Wuhan City, Hubei province, China. ${ }^{2}$ On January 8, 2020, the pathogen causing this form of pneumonia was identified as the newest member of the coronavirus family confirmed to cause disease in humans. ${ }^{3}$ Clinical epidemiological studies and characterization of affected patients soon followed. ${ }^{4}$ Prior to the identification of this new virus, there were 6 known human coronaviruses, of which 4 cause only minor cold-like symptoms, but 2 cause more serious illnesses: Severe Acute Respiratory Syndrome coronavirus (SARS$\mathrm{CoV}$ ) and Middle East Respiratory Syndrome coronavirus (MERS-CoV).

In the relatively short time span of 3 months since the new coronavirus was identified, the literature on COVID-19 has grown exponentially, from not a single scientific report to over 1600 publications at the time of this writing, across numerous disciplines in the field of medicine, including infectious disease, virology, epidemiology, immunology, critical care medicine, pediatrics, medical education, psychiatry, and surgery. Just now, neurosurgical programs from Wuhan, China, are submitting articles to the Journal describing their experiences combating COVID-19 in their hospitals. According to these reports, endoscopic endonasal skull base procedures should be avoided as much as possible given the high likelihood of aerosolizing virus particles within the nasal sinuses and infecting operating room staff.

In 2003, SARS-CoV gripped the world. More than 8000 total cases of SARS-CoV were reported following the initial outbreak of cases in the Guangdong province of China in 2002. In 2003, the city of Toronto was the site of a large cluster of infected individuals, with over 400 cases documented. Large international meetings planned in Toronto, such as the American Association of Cancer
Research annual meeting, the largest cancer research meeting of its kind in the world, were cancelled due to the SARS epidemic. Now, with the COVID-19 pandemic, virtually all the conferences of organized neurosurgical associations and societies around the world have been either cancelled or postponed. International airplane travel is forbidden in most countries. National travel is being discouraged. Practices of self-isolation and social distancing have become the norm.

As the numbers of new COVID-19 cases appear to be flattening in China at the time of the writing of this introduction, a wave of new COVID-19 infections is striking Europe, South America, and North America at an alarming rate. While COVID-19 has limited neurovirulence, its reproductive number $\left(\mathrm{R}_{0}\right)$ is high, indicating that its transmissibility gives it the potential to infect large proportions of the world population, with enough patients with severe symptoms to overwhelm our healthcare systems, as has been demonstrated in jurisdictions such as northern Italy. The many COVID-19 patients requiring admission to critical care and intensive care units have already led to the prioritization of neurosurgical cases throughout North America.

For these reasons, we thought it prudent to share up-todate information regarding the best neurosurgical practices during the COVID-19 pandemic. We hope these timely communications will lead to better preparedness for taking care of our patients and maintaining the safety and wellbeing of all healthcare workers on the front lines, while enabling us to continue to promote innovations through educational and teaching opportunities that may take place outside the operating room. In addition, perhaps there will be an increased focus on basic and translational viral science that will lead to more rapid therapeutic responses.

Accordingly, a series of rapid-communication editorials has been commissioned by the Journal of Neurosurgery Publishing Group (JNSPG) from neurosurgeons in regions severely affected by COVID-19, such as China, South Korea, Singapore, and Italy. We provide communications on the impact of COVID-19 on the practice of particular aspects of neurosurgery (Fig. 1), such as general and spe- 


$$
\begin{aligned}
& \text { PATIENT SAFETY } \\
& \text { NEUROSURGERYCLIN/C } \\
& \begin{array}{l}
\text { NEUROSURGERY OPERATING } \\
\text { INTENSIVE CARE UNITS }
\end{array} \\
& \begin{array}{l}
\text { PERONAL PROTECTIVE EQU/D MEN ECONOMIC IMPACT } \\
\text { ECNT }
\end{array} \\
& \text { COMMUNICATION TOO }{ }{ }^{2}
\end{aligned}
$$

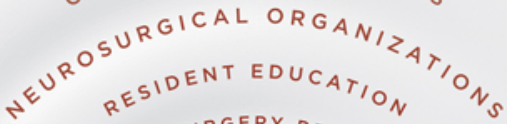

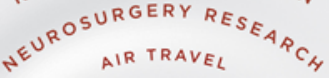

$$
\begin{aligned}
& \text { (C) }
\end{aligned}
$$

FIG. 1. Impact of COVID-19 on the practice of neurosurgery. Clinical care, neurosurgical procedures, resident/fellow education, neurosurgical research, neurosurgical organizations, national and international travel, and the world economy have all been dramatically altered by the pandemic. New systems are being designed and implemented to offset many of the downstream, deleterious effects of COVID-19. Figure is available in color online only.

cialized adult neurosurgery, spine surgery, and pediatric neurosurgery. The effects of the COVID-19 pandemic on annual neurosurgical meetings, such as the American Association of Neurological Surgeons (AANS), are discussed by Kathleen Craig, Chief Executive Officer, and Chris Shaffrey, President of the AANS. The downstream effects of a reduction in operative experience and formal in-person conferencing on resident education are described in an editorial prepared by neurosurgery residency program directors. In this regard, the importance of web-based conferencing systems has emerged and reached primacy. The effects of COVID-19 on large academic neurosurgical units versus small private neurosurgical practices are compared and contrasted. Members of the Editorial Board of the JNSPG for all three print journals were asked to collate and prepare their experiences in the form of an editorial from across the United States and beyond. And finally, as issues arise when allocating scarce medical resources during pandemics, we present an editorial on the ethics of prioritizing and rationing neurosurgical care during the COVID-19 pandemic.

In a Ted Talk delivered in 2014, Bill Gates warned that we were ill prepared for the next global catastrophic event, which he predicted would be from another uncontrolled viral epidemic. 5

Despite what we learned from prior epidemics, such as SARS, Ebola, and MERS, the words of Gates and others now appear to have been prophetic. While it is important to recognize the impact of COVID-19 on the practice of neurosurgery through this series of rapid communications in the Journal, it will be equally important to "debrief" on where we will be 6 to 12 months from now. It is our strong hope that we will be able to codify systems of containment so that we can immediately prevent or minimize the spread of diseases such as COVID-19; that we develop standardized systems of care so that a necessary and required stock of personal protective equipment (PPE) is always available; and that we work together to ensure that the prioritization of the care of acutely ill neurosurgical patients is forever seamless, even at times of limited inpatient hospital resources. Through arduous training processes and previous experiences, neurosurgeons are by nature a resilient group of surgical specialists. Accordingly, we hope to demonstrate that our responses to the COVID-19 pandemic will make our specialty stronger, and better prepared for the future.

https://thejns.org/doi/abs/10.3171/2020.3.JNS201007

\section{Addendum}

On the day this piece was submitted, March 30, 2020, we learned of the passing of fellow neurosurgeon Dr. James T. Goodrich, Chief of Pediatric Neurosurgery, Montefiore Medical Center, New York City, from complications related to COVID-19.

\section{References}

1. Bogoch II, Watts A, Thomas-Bachli A, et al. Pneumonia of unknown aetiology in Wuhan, China: potential for international spread via commercial air travel. J Travel Med. 2020;27(2):taaa008.

2. Pneumonia of unknown cause. January 5, 2020. World Health Organization. Accessed March 30, 2020. https://www. who.int/csr/don/05-january-2020-pneumonia-of-unkowncause-china/en/

3. ProMED. Undiagnosed pneumonia - China (HU) (07): official confirmation of novel coronavirus. January 8 , 2020. International Society for Infectious Diseases. Accessed March 30, 2020. https://promedmail.org/promedpost $/$ ?id=20200108.6878869

4. Zhu N, Zhang D, Wang W, et al. A novel coronavirus from patients with pneumonia in China, 2019. N Engl J Med. 2020;382(8):727-733.

5. Gates B. The next outbreak? We're not ready. TED2015. Accessed March 30, 2020. https://www.ted.com/talks/bill_ gates_the_next_outbreak_we_re_not_ready

\section{Disclosures}

The authors report no conflict of interest.

\section{Correspondence}

James T. Rutka: james.rutka@sickkids.ca.

\section{INCLUDE WHEN CITING}

Published online April 10, 2020; DOI: 10.3171/2020.3.JNS201007. 